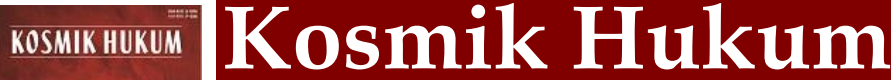

\author{
Fakultas Hukum
}

Universitas Muhammadiyah Purwokerto

Vol. 20 No. 1 (2020)

This work is licensed under a Creative Commons Attribution 4.0 International License (cc-by)

\section{Aspek Hukum Perlindungan Data Konsumen E-Commerce}

\author{
Ardiana Hidayah1四, Marsitiningsih2 \\ 1 Fakultas Hukum Universitas Palembang \\ 2 Fakultas Hukum Universitas Muhammadiyah Purwokerto \\ E-mail: ardyanah@yahoo.co.id
}

\begin{abstract}
Consumer data protection is part of the consumer protection aspect of online transactions or e-commerce activities. This research is a normative legal research based on library research. This study aims to know and understand that personal data is part of the constitutional rights of citizens, so that the state is obliged to protect dignity, respect and integrity of consumers as human beings. The use of any information through electronic media that involves a person's personal data must be done with the consent of the person concerned. The misuse of consumer data is a major problem in legal protection to consumers. Consumer data protection only relies on Ministerial Regulation Number 20 Year 2016 concerning Protection of Personal Data which cannot be used as a basis for solving the problem of data misuse. There needs to be a special institution in processing law enforcement in the context of protecting consumer data.
\end{abstract}

Keywords: Consumer Data Protection.

\begin{abstract}
Abstrak
Perlindungan data konsumen merupakan bagian dari aspek perlindungan konsumen dalam transaksi online ataupun kegiatan e-commerce. Penelitian ini merupakan penelitian hukum normatif yang berdasarkan pada penelitian kepustakaan (library research). Penelitian ini bertujuan untuk mengetahui dan memahami bahwa data pribadi bagian dari hak konstitusional warga negara, sehingga negara wajib melindungi harga diri (dignity), kehormatan (respect) dan juga integritas (integrity) konsumen sebagai manusia. Penggunaan setiap informasi melalui media elektronik yang menyangkut data pribadi seseorang harus dilakukan atas persetujuan orang yang bersangkutan. Penyalagunaan data konsumen menjadi permasalahan besar dalam perlindungan hukum kepada konsumen. Perlindungan data konsumen hanya bersandar pada Peraturan Menteri (Permen) Nomor 20 Tahun 2016 tentang Perlindungan Data Pribadi yang secara landasan hukum belum dapat dijadikan dasar penyelesaian masalah penyalahgunaan data. Perlu adanya suatu lembaga khusus dalam memproses penegakan hukum dalam rangka perlindungan data konsumen.
\end{abstract}

Kata Kunci: Perlindungan Data Konsumen

Copyright@2020KosmikHukum. All rights reserved.

\section{Pendahuluan}

Terjadi perubahan besar dalam penggunaan dan pemanfaatan kemajuan teknologi bagi manusia. Munculnya teknologi informasi melahirkan era baru dalam lingkungan kegiatan bisnis di seluruh belahan bumi. Penggunaan teknologi yang berdampak pada sistem bisnis modern yang mengarah pada perdagangan bebas dengan menggunakan media elektronik.12

Perkembangan teknologi informasi dan komunikasi yang terus bergerak cepat telah menimbulkan berbagai peluang dan tantangan. Teknologi informasi memungkinkan manusia untuk saling terhubung tanpa mengenal batas-batas wilayah negara sehingga merupakan salah satu faktor pendorong globalisasi. Berbagai sektor kehidupan telah memanfaatkan sistem

Edy Santoso, (2018), Pengaruh Era Globalisasi terhadap Hukum Bisnis di Indonesia, Kencana, Jakarta, hlm.174

Murti Ali Lingga (2019), Penyalahgunaan Data Pribadi Konsumen Sudah Masuk Katagori Gawat Darurat. Diunduh dari: https://money.kompas.com/read/2019/07/27/201200426/penyalahgunaan-data-pribadi-konsumen-s udahmasuk-katagori-gawat-darurat?page=all,, tanggal 10 September 2019 
teknologi informasi, seperti penyelenggaraan electronic commerce (e-commerce) dalam sektor perdagangan/bisnis, electronic education (e-education) dalam bidang pendidikan, electronic health (e-health) dalam bidang kesehatan, electronic government (e-government) dalam bidang pemerintahan serta teknologi informasi yang dimanfaatkan dalam bidang lainnya. Pemanfaatan teknologi informasi tersebut mengakibatkan data dan informasi pribadi seseorang sangat mudah untuk dikumpulkan dan dipindahkan dari satu pihak ke pihak lain tanpa sepengetahuan subjek data dan informasi pribadi, sehingga mengancam hak atas privasi seseorang.

Perlindungan atas data pribadi adalah termasuk ke dalam perlindungan hak asasi manusia, dengan demikian, pengaturan menyangkut hak privasi atas data pribadi merupakan manifestasi pengakuan dan perlindungan atas hak-hak dasar manusia. Pergaulan internasional Indonesia turut menuntut adanya perlindungan atas data dan informasi pribadi. Perlindungan tersebut dapat memperlancar perdagangan, industri, investasi yang bersifat transnasional.

Manusia sebagai pribadi bagian dalam hidup bermasyarakat yang kapasitasnya sebagai konsumen diberikan kemudahan dalam segala hal, khususnya dalam melakukan bisnis dan transaksi secara online (e-commerce). Kemajuan teknologi tidak hanya memiliki sisi positif, tapi juga sisi negatif yakni mengakibatkan adanya penyalahgunaan data pribadi konsumen. Pelaku dalam penyalahgunaan data beragam mulai dari financial technology (fintech), bank, maupun oknum lainnya.

Berdasarkan data-data yang dikemukakan Alvin Lie Anggota Ombudsman Republik Indonesia menyatakan bahwa saat ini penyalahgunaan data-data konsumen/masyarakat oleh oknum perusahaan tertentu sudah sangat parah. Hal tersebut disebabkan karena data yang dimiliki bisa disalahgunakan. Saat ini data pribadi konsumen belum terlindungi oleh peraturan secara khusus. Masih belum adanya Undang-undang maupun Peraturan Pemerintah (PP) yang dibuat serta disahkan untuk memberikan pelindungan kepada warga negara.

Belum adanya perlindungan kepada konsumen melalui aturan pemerintah yang menyebabkan oknum tertentu berani dalam melakukan penyalahgunaan data-data masyarakat. Terdapat data-data konsumen pada perusahaan tertentu dapat dengan mudah diperjualbelikan bahkan disalahgunakan.

Perlindungan data konsumen masih belum terlindungi secara hukum .Jika terdapat kasus yakni seseorang yang menjadi korban penyalahgunaan data pribadi, maka akan sangat sulit dalam menyelesaikannya. Saat ini masih belum ada lembaga atau penegak hukum yang khusus dalam memproses dan menyelesaikan persoalan ini.

Payung hukum atau landasan hukum yang dapat dijadikan acuan dalam perlindungan data hanya terbatas Peraturan Menteri. Saat ini permasalahan data konsumen masih bersandar pada Peraturan Menteri (Permen) yang dikeluarkan Menteri Komunikasi dan Informatika (Menkominfo) Nomor 20 Tahun 2016 tentang Perlindungan Data Pribadi.

Sebagai negara hukum, Indonesia menjadikan hukum sebagai panglima dalam menjalankan kehidupan berbangsa dan bernegara, hukum seyogyanya harus melindungi hakhak warga negaranya.3 Data pribadi bagian dari hak konstitusional

\section{Metode Penelitian}

Penelitian ini merupakan penelitian hukum normatif yang berdasarkan pada penelitian kepustakaan (library research). Penelitian hukum normatif, maksudnya adalah penelitian yang menggambarkan, menelaah, menjelaskan serta menganalisis permasalahan mengenai perlindungan data konsumen sebagai bagian dari aspek perlindungan konsumen dalam transaksi online ataupun kegiatan e-commerce.

Penelitian ini bertujuan untuk mengetahui dan memahami perlindungan data konsumen, serta mengetahui dan menganalisis bahwa data pribadi bagian dari hak 
Kosmik Hukum Vol. 20 No. 1 (2020): 56-63

E-ISSN: 2655-9242 | P-ISSN: 1411-9781

DOI: 10.30595/kosmikhukum.v20i1.8251

konstitusional warga negara, sehingga negara wajib melindungi harga diri (dignity), kehormatan (respect) dan juga integritas (integrity) konsumen sebagai manusia.

Terdapat beberapa pendekatan yang dilakukan terhadap permasalahan yang diteliti, untuk kemudian dikaji dari berbagai aspek hukum yang ada hubungannya dengan isu hukum (legal issue) yang diteliti. Adapun metode pendekatan masalah dalam penelitian adalah:

a. Pendekatan Filsafat (Philosophi Approach)

Pendekatan filsafat digunakan untuk mengkaji asas-asas hukum yang terkandung dalam ketentuan perlindungan konsumen dan perlindungan data sebagai konsumen.

b. Pendekatan Perundang-undangan (Statute Approach)

Pendekatan perundang-undangan dilakukan dengan menelaah semua undang-undang dan regulasi yang bersangkut paut dengan isu hukum yang sedang ditangani. Pendekatan perundang-undangan ini digunakan untuk memperoleh deskripsi analisis peraturan hukum yang mengatur mengenai hukum perlindungan konsumen dalam kapasitasnya terhadap perlindungan data konsumen.

c. Pendekatan Historis (Historical Approach)

Pendekatan historis digunakan untuk menelaah latar belakang atau sejarah dikeluarkannya peraturan hukum, khususnya yang mengatur tentang perlindungan konsumen terkait perlindungan data konsumen di Indonesia.

d. Pendekatan Konseptual (Conceptual Approach)

Pendekatan konseptual beranjak dari pandangan-pandangan dan doktrin-doktrin yang berkembang di dalam ilmu hukum. Dengan mempelajari pandangan-pandangan dan doktrin-doktrin di dalam ilmu hukum, peneliti akan menemukan ide-ide yang melahirkan pengertian-pengertian hukum, konsep-konsep hukum dan asas-asas hukum yang relevan dengan isu yang

dihadapi.4

\section{Hasil dan Pembahasan}

\section{Diskresi Sebagai Instrumen Pelayanan Publik (Public Service)}

Merujuk pada Rancangan Undang-Undang Perlindungan data, dirumuskan bahwa data pribadi adalah setiap data tentang kehidupan seseorang baik yang teridentifikasi dan/atau dapat diidentifikasi secara tersendiri atau dikombinasi dengan informasi lainnya baik secara langsung maupun tidak langsung melalui sistem elektronik dan/atau non elektronik. Apabila dikaitkan dengan data konsumen dalam kegiatan e-commerce, maka erat hubungannya dengan perlindungan konsumen dalam hal data pribadinya.

Perlindungan konsumen yang diatur dalam Undang-Undang Nomor 8 Tahun 1998. Perlindungan konsumen berdasarkan asas-asas berikut ini:

1. Asas manfaat: pengaturan mengenai perlindungan konsumen akan dapat dimanfaatkan secara optimal bagi kemanusiaan, peningkatan kesejahteraan rakyat dan pembangunan probadi setiap negara.

2. Asas keadilan: pengaturan mengenai perlindungan konsumen akan dapat memberikan rasa keadilan bagi setiap masyarakat konsumen pada umumnya.

Peter Mahmud Marzuki, (2010), Penelitian Hukum, Prenada Media Group, Jakarta, ( hlm. 93) 5 Peter Mahmud Marzuki, Ibid, (hlm.95)

4 Wahyu Utami dan Yogabakti Adipradana, (2017), Pengantar Hukum Bisnis dalam Perspektif Teori dan Praktiknya di Indonesia, Jala Permata Aksara, Jakarta, (hlm. 127) 
3. Asas keseimbangan: pengaturan mengenai perlindungan konsumen akan dapat menciptakan keseimbangan antara kepentingan konsumen dan kepentingan produsen.

4. Asas keamanan dan keselamatan konsumen: pengaturan mengenai perlindungan konsumen akan dapat memberikan suasana kondusif bagi konsumen dalam rangka penggunaan hasil produk dari produsen.

5. Asas kepastian hukum: pengaturan mengenai perlindungan konsumen akan dapat memberikan suatu kepastian hukum berkenaan dengan hak dan kewajiban antara konsumen dan produsen.

Tujuan perlindungan konsumen berdasarkan Pasal 3 Undang-Undang Nomor 8 Tahun 1998 adalah sebagai berikut:

1. Meningkatkan kesadaran, kemampuan dan kemandirian konsumen untuk melindungi diri.

2. Mengangkat harkat dan martabat konsumen dengan cara menghindarkannya dari ekses negatif pemakaian barang dan/atau jasa.

3. Meningkatkan pemberdayaan konsumen dalam memilih, menentukan, dan menuntut hak-haknya sebagai konsumen.

4. Menciptakan sistem perlindungan konsumen yang mengandung unsur kepastian hukum dan keterbukaan informasi serta akses untuk mendapatkan informasi.

5. Menumbuhkan kesadaran pelaku usaha mengenai pentingnya perlindungan konsumen sehingga tumbuh sikap yang jujur dan bertanggungjawab dalam berusaha.

6. Meningkatkan kualitas barang dan/atau jasa yang menjamin kelangsungan usaha produksi barang dan/atau jasa, kesehatan, kenyamanan, keamanan, dan keselamatan konsumen.

Data Pribadi bersifat sensitif oleh karena itu, data pribadi diperlukan perlindungan khusus, data tersebut terdiri dari data yang berkaitan dengan agama/keyakinan, kesehatan, kondisi fisik dan kondisi mental, kehidupan seksual, data keuangan pribadi, dan data pribadi lainnya yang mungkin dapat membahayakan dan merugikan privasi subjek data.

Perlindungan data konsumen berdasarkan pada asas perlindungan, asas kepentingan umum, asas keseimbangan yang proporsional, dan asas pertanggungjawaban. Asas perlindungan memberi perlindungan kepada pemilik data mengenai privasinya, mengenai data pribadinya, mengenai hak-haknya atas data agar data tersebut tidak disalahgunakan sehingga merugikan kepentingan pemilik data. Asas kepentingan umum sangat penting untuk dapat dijadikan alasan yang sah sebagai alasan untuk menerobos atau alasan pengecualian terhadap perlindungan privasi atas data.

pribadi. Kepentingan umum tersebut meliputi, antara lain: keamanan negara, kedaulatan negara, pemberantasan korupsi dan tindak pidana lainnya. Asas keseimbangan dijadikan dasar bagi perumusan norma pada Perlindungan Data Pribadi, aturan ini mencerminkan upaya untuk menyeimbangkan antara hak-hak privasi di satu pihak dengan hak-hak negara yang sah berdasarkan kepentingan umum, sesuai dengan porsinya masing-masing. Asas pertanggungjawaban memberi landasan bagi semua pihak yang terkait dengan pemrosesan, penyebarluasan, pengelolaan, dan pengawasan data pribadi untuk bertindak secara bertanggung jawab sehingga mampu menjamin keseimbangan hak dan kewajiban para pihak yang terkait, termasuk pemilik data.

Perlunya pengaturan atas perlindungan data pribadi bertujuan untuk: 1) Melindungi dan menjamin hak dasar warga negara terkait dengan privasi atas data pribadi; 2) Menjamin masyarakat untuk mendapatkan pelayanan dari pemerintah, pelaku bisnis dan organisasi kemasyarakatan lainnya; 3) Mendorong pertumbuhan industri teknologi, informasi dan komunikasi; 4) Mendukung peningkatan daya saing industri dalam negeri. 
Kosmik Hukum Vol. 20 No. 1 (2020): 56-63

E-ISSN: 2655-9242 | P-ISSN: 1411-9781

DOI: 10.30595/kosmikhukum.v20i1.8251

Indonesia secara umum memiliki regulasi hukum yang mengatur mengenai rahasia pribadi (privacy policy) dalam online marketplace system pada kegiatan $e$-commerce, yaitu terdapat dalam UndangUndang Nomor 11 tahun 2008 tentang Informasi dan Transaksi Elektronik (UU Nomor 18 Tahun 2008 tentang ITE) dan

Peraturan Pemerintah Nomor 28 tahun 2012 tentang Penyelenggaraan Sistem dan Transaksi Elektronik (PP Nomor 28 Tahun 2012 tentang PSTE). Salah satu lead sector Pemerintah Indonesia yang menangani e-commerce adalah Kementerian Komunikasi dan Informasi (Kemenkominfo). 5 Tujuan dari regulasi hukum memberikan klausul baku kepada calon konsumen pada aplikasi $e$-commerce agar dapat secara adil dan terbuka untuk disepakati kedua belah pihak. Dalam konteks ini negara bersifat justice and fairness dalam menjadi "pihak ditengah-tengah" dan menjadi pihak yang mengkontrol privacy policy yang dirumuskan disepakati oleh penyedia jasa e-commerce/penjual dengan konsumen terkait dengan data privasi yang dilakukan secara daring.

Pengaturan atas perlindungan data pribadi diatur melalui Peraturan Menteri Komunikasi dan Informatika. Pada tanggal 1 Desember 2016, Pemerintah Republik Indonesia mengundangkan Peraturan Menteri Komunikasi dan Informatika Republik Indonesia Nomor 20 Tahun 2016 tentang Perlindungan Data Pribadi dalam Sistem Elektronik (Permenkominfo 20/2016 ). Permenkominfo 20/2016 merupakan peraturan pelaksanaan dari Peraturan Pemerintah Nomor 82 Tahun 2012 tentang Penyelenggaraan Sistem dan Transaksi Elektronik, yang mengamanatkan agar pedoman perlindungan data pribadi dalam sistem elektronik untuk diatur lebih lanjut dalam peraturan Menteri Komunikasi dan Informatika.

Data pribadi berdasarkan Permenkominfo 20/2016 adalah data perseorangan tertentu yang disimpan, dirawat, dan dijaga kebenarannya serta dilindungi kerahasiaannya. Adapun data perseorangan tertentu adalah setiap keterangan yang benar dan nyata yang melekat dan dapat diidentifikasi, baik langsung maupun tidak langsung, pada masing-masing individu yang pemanfaatannya sesuai ketentuan peraturan perundang-undangan.6 Perlindungan data pribadi dalam sistem elektronik dilakukan pada proses: Perolehan dan pengumpulan; Pengolahan dan penganalisisan; Penyimpanan; Penampilan, pengumuman, pengiriman, penyebarluasan, dan/atau pembukaan akses; dan Pemusnahan.

Peraturan pada perlindungan data akan melindungi data pribadi individu terhadap penyalahgunaan pada saat data tersebut memiliki nilai tinggi untuk kepentingan bisnis. Perkembangan pengaturan terhadap perlindungan data pribadi secara umum akan menempatkan Indonesia sejajar dengan negara-negara dengan tingkat perekonomian yang maju, yang telah menerapkan hukum mengenai perlindungan data pribadi. Perlindungan data pribadi di negara Indonesia akan menjadi negara sebagai pusat bisnis dan investasi tepercaya, yang merupakan suatu strategi kunci dalam perkembangan ekonomi.

Terkait perlindungan dan kepentingan konsumen, kebutuhan akan perlindungan data pribadi konsumen terutama di era di mana data pribadi menjadi sangat berharga untuk kepentingan bisnis, menimbulkan kekhawatiran bahwa data pribadi konsumen dapat dijualbelikan atau digunakan tanpa persetujuan konsumen sebagai bentuk pelanggaran. Oleh karena itu, perlindungan data pribadi yang bersifat khusus dalam suatu undang-undang sangat diperlukan guna memastikan bahwa data pribadi konsumen dilindungi dengan baik.

Pada perkembangan bidang ekonomi, perlindungan data pribadi yang bersifat khusus akan memperkuat posisi Indonesia sebagai pusat bisnis dan investasi tepercaya dan menciptakan lingkungan yang kondusif untuk pertumbuhan manajemen data global dan industri pengolahan data yang terus berkembang di Indonesia. Ketiadaan hukum mengenai

\footnotetext{
Masitoh Indriyani et.al, (2017) Perlindungan Privasi dan Data Pribadi Konsumen Daring pada Online Marketplace, Justitia Jurnal Hukum Fakultas Hukum Universitas Muhammadiyah Surabaya. Diunduh dari: http://journal.umsurabaya.ac.id/index.php/Justitia/article/view/1152/823, tanggal 10 September 2019. (hlm. 196)

6 Perlindungan Data Pribadi dalam Sistem Elektronik. Diunduh dari: http:/ / www.hukumperseroanterbatas.com/articles/perlindungan-data-pribadi-dalam-sistem-elektronik/, tanggal 17 September 2019
} 
perlindungan data pribadi yang bersifat umum di Indonesia dapat dilihat sebagai suatu kelemahan yang menyebabkan beberapa perusahaan tidak memilih Indonesia sebagai lokasi untuk pusat penyimpanan datanya. Padahal, perkembangan pengaturan perlindungan data pribadi akan mendukung pembangunan masa depan Indonesia sebagai pusat data global.

\section{Perlindungan Data Bagian dari Hak Konstitusional Warga Negara}

Sejak berdirinya Negara Kesatuan Republik Indonesia (NKRI) Tahun 1945, negara telah menjunjung tinggi pelaksanaan Hak Asasi Manusia (HAM). Hal tersebut terkandung dalami pancasila dan UUD 1945, yang memuat beberapa ketentuan tentang penghormatan HAM warga negara. Sehingga pada praktek penyelenggaraan negara, perlindungan atau penjaminan terhadap HAM dan hak-hak warga negara (citizen's right) atau hak-hak konstitusional warga negara (the citizen's constitutional rights) dapat terlaksana.7

Negara Indonesia berdasar atas hukum yang menempatkan hukum sebagai hal yang tertinggi (supreme) sehingga ada istilah supremasi hukum. Supremasi hukum berdasarkan 3 (tiga) ide dasar hukum yaitu keadilan, kemanfaatan, dan kepastian.

Indonesia sebagai negara hukum, pemerintahan negara harus berdasarkan atas suatu konstitusi atau Undang-Undang Dasar sebagai landasan penyelenggaraan pemerintahan. Konstitusi dalam negara hukum adalah konstitusi yang bercirikan gagasan konstitusionalisme yaitu adanya pembatasan atas kekuasaan dan jaminan hak dasar warga negara.8 Hak konstitusional merupakan bagian dari hak-hak warga negara yang dijamin dalam konstitusi Undang-Undang Dasar Negara Republik Indonesia Tahun 1945.

Menurut Arief Sidharta, Scheltema merumuskan pandangannya tentang unsur-unsur dan asas-asas Negara Hukum itu secara baru, yaitu meliputi 5(lima) hal sebagai berikut:9

1. Pengakuan, penghormatan, dan perlindungan hak asasi manusia yang berakar dalam penghormatan atas martabat manusia (human dignity).

2. Berlakunya asas kepastian hukum. Negara Hukum untuk bertujuan menjamin bahwa kepastian hukum terwujud dalam masyarakat. Hukum bertujuan untuk mewujudkan kepastian hukum dan prediktabilitas yang tinggi, sehingga dinamika kehidupan bersama dalam masyarakat bersifat' predictable'.

3. Berlakunya Persamaan (Similia Similius atau Equality before the Law), dalam negara hukum, Pemerintah tidak boleh mengistimewakan orang atau kelompok orang tertentu, atau mendiskriminasikan orang atau kelompok orang tertentu. Di dalam prinsip ini, terkandung (a) adanya jaminan persamaan bagi semua orang dihadapan hukum dan pemerintahan, dan (b) tersedianya mekanisme untuk menuntut perlakuan yang sama bagi semua warga negara.

4. Asas demokrasi dimana setiap orang mempunyai hak dan kesempatan yang sama untuk turut serta dalam pemerintahan atau untuk mempengaruhi tindakan-tindakan pemerintahan.

5. Pemerintah dan pejabat mengemban amanat sebagai pelayan masyarakat dalam rangka mewujudkan kesejahteraan masyarakat sesuai dengan tujuan bernegara yang bersangkutan.

Pentingnya Menjaga Hak Konstitusional Warga Negara di Indonesia. Diunduh dari: https://www.uii.ac.id/ pentingnya-menjaga-hak-konstitusional-warga-negara-di-indonesia/, tanggal 15 September 2019

\& Naskah Akademik RUU Perlindungan Data Pribadi (hlm. 14). Diunduh dari: https://www.bphn.go.id/ data/documents/na_perlindungan_data_pribadi.pdf, tanggal 16 September 2019

9 B. Arief Sidharta, (2004), Kajian Kefilsafatan tentang Negara Hukum, Jentera (Jurnal Hukum), "Rule of Law”, Pusat Studi Hukum dan Kebijakan (PSHK), Jakarta, edisi 3 Tahun II, November, (hlm.124-125) dalam Naskah Akademik RUU Perlindungan Data Pribadi (hlm.11-13). Diunduh dari: https://www.bphn.go.id/data/documents/ na_perlindungan_data_pribadi.pdf, tanggal 16 September 2019 
Kosmik Hukum Vol. 20 No. 1 (2020): 56-63

E-ISSN: 2655-9242 | P-ISSN: 1411-9781

DOI: 10.30595/kosmikhukum.v20i1.8251

Pengertian hak asasi manusia merupakan hak kodrati yang dibawa oleh manusia sejak manusia lahir ke dunia. Pemahaman terhadap hak asasi tersebut merupakan pemahaman yang sangat umum dengan tanpa membedakan secara akademik hak-hak yang dimaksud serta tanpa mempersoalkan asal-usul atau sumber diperolehnya hak tersebut. Hak Asasi Manusia10 adalah hak-hak yang dimiliki manusia semata-mata karena ia manusia. Umat manusia memilikinya bukan karena diberikan kepadanya oleh masyarakat atau berdasarkan hukum positif, melainkan semata-mata berdasarkan martabatnya sebagai manusia. Dalam arti ini, maka meskipun setiap orang terlahir dengan warna kulit, jenis kelamin, bahasa, budaya dan kewarganegaraan yang berbeda-beda, tetapi tetap mempunyai hak-hak tersebut. Inilah sifat universal dari hak-hak tersebut. Selain bersifat universal, hak-hak itu juga tidak dapat dicabut (inalienable).

Perlindungan Data Pribadi merupakan amanat dari Pasal 28G ayat (1) Undang-Undang Dasar Negara Republik Indonesia Tahun 1945 yang menyatakan bahwa: "setiap orang berhak atas perlindungan diri pribadi, keluarga, kehormatan, martabat, dan harta benda yang di bawah kekuasaannya, serta berhak atas rasa aman dan perlindungan dari ancaman ketakutan untuk berbuat atau tidak berbuat sesuatu yang merupakan hak asasi". Persoalan perlindungan terhadap data pribadi muncul karena keprihatinan akan pelanggaran privasi yang dapat dialami oleh orang dan atau badan hukum. Pelanggaran privasi tersebut dapat menimbulkan kerugian yang tidak hanya bersifat materiil tetapi juga moril yaitu berupa hancurnya nama baik seseorang atau lembaga. Sehingga data pribadi sebagai bagian dari hak konstitusional warga negara, maka negara wajib melindungi harga diri (dignity), kehormatan (respect) dan juga integritas (integrity) konsumen sebagai manusia.

Data pribadi merupakan pengakuan dan perlindungan atas hak-hak dasar manusia yang telah dilindungi berdasarkan Hukum Internasional, Regional dan Nasional. Perlindungan privasi atas data pribadi sebagai hak asasi yang diamanatkan langsung oleh konstitusi Negara Republik Indonesia. Terkait privasi atas data pribadi adalah kebutuhan untuk melindungi hakhak individual di dalam masyarakat sehubungan dengan pengumpulan, proses, penyelenggaraan, dan penyebarluasan data pribadi. Perlindungan pada data pribadi memberikan kepercayaan masyarakat untuk menyediakan data dan/atau informasi pribadi untuk kepentingan masyarakat luas tanpa disalahgunakan atau melanggar hak-hak pribadinya.

\section{Penutup}

\section{Kesimpulan}

Perlindungan data konsumen bersandar pada Peraturan Menteri (Permen) Nomor 20 Tahun 2016 tentang Perlindungan Data Pribadi yang secara landasan hukum. Perlindungan data konsumen sebagai bagian dari aspek perlindungan konsumen dalam transaksi online ataupun kegiatan e-commerce. Data pribadi bagian dari hak konstitusional warga negara, sehingga negara wajib melindungi harga diri (dignity), kehormatan (respect) dan juga integritas (integrity) konsumen sebagai manusia. Penggunaan setiap informasi melalui media elektronik yang menyangkut data pribadi seseorang harus dilakukan atas persetujuan orang yang bersangkutan. Penyalagunaan data konsumen menjadi permasalahan besar dalam perlindungan hukum kepada konsumen.

Keberadaan suatu Undang-Undang tentang Perlindungan atas Data Pribadi merupakan suatu keharusan yang tidak dapat ditunda-tunda lagi karena sangat mendesak bagi berbagai kepentingan nasional. Undang-Undang Perlindungan Data Pribadi menjadi kunci dalam memperkuat perlindungan konsumen pada era ekonomi digital. Dipandang juga perlu adanya

10 Knut D. Asplund, Suparman Marzuki dan Eko Riyadi, (ed.), (2008) Hukum Hak Asasi Manusia, Pusat Studi Hak Asasi Manusia Universitas Islam Indonesia, PUSHAM UII, Yogyakarta, (hlm.11) dalam Naskah Akademik RUU Perlindungan Data Pribadi (hlm. 16). Diunduh dari: https://www.bphn.go.id/data/documents/ na_perlindungan_data_pribadi.pdf, tanggal 16 September 2019 
suatu lembaga khusus dalam penanganan penegakan hukum dalam rangka perlindungan data konsumen.

\section{Daftar Pustaka}

B. Arief Sidharta, (2004), Kajian Kefilsafatan tentang Negara Hukum, Jentera (Jurnal Hukum), Rule of Law, Pusat Studi Hukum dan Kebijakan (PSHK), Jakarta, edisi 3 Tahun II, November.

Edy Santoso, (2018), Pengaruh Era Globalisasi terhadap Hukum Bisnis di Indonesia, Kencana, Jakarta.

Masitoh Indriyani et.al, (2017) Perlindungan Privasi dan Data Pribadi Konsumen Daring pada Online Marketplace, Justitia Jurnal Hukum Fakultas Hukum

Universitas Muhammadiyah Surabaya. Diunduh dari:

http://journal.um-surabaya.ac.id/index.php/Justitia/article/view/1152/823, tanggal 10 September 2019

Murti Ali Lingga (2019), Penyalahgunaan Data Pribadi Konsumen Sudah Masuk
Katagori
Gawat
Darurat.
Diunduh
dari:

https://money.kompas.com/read/2019/07/27/201200426/penyalahgunaan-data pribadi-konsumen-sudah-masuk-katagori-gawat-darurat?page=all,${ }^{\prime} \quad$ tanggal 10 September 2019

Hak Konstitusional Warga Negara, Diunduh dari:

http://ditjenpp.kemenkumham.go.id/htn-dan-puu/2971-hak-konstitusional-wa rganegara.html, tanggal 15 September 2019

Knut D. Asplund, Suparman Marzuki dan Eko Riyadi, (ed.), (2008) Hukum Hak Asasi Manusia, Pusat Studi Hak Asasi Manusia Universitas Islam Indonesia, PUSHAM UII, Yogyakarta.

Peter Mahmud Marzuki, (2010), Penelitian Hukum, Prenada Media Group, Jakarta.

Wahyu Utami dan Yogabakti Adipradana, (2017), Pengantar Hukum Bisnis dalam Perspektif Teori dan Praktiknya di Indonesia, Jala Permata Aksara, Jakarta.

Rancangan Undang-Undang Perlindungan Data Pribadi

Perlindungan Data Pribadi dalam Sistem Elektronik. Diunduh dari:

http://www.hukumperseroanterbatas.com/articles/perlindungan-data-pribadi-d alam-sistem-elektronik/,tanggal 17 September 2019

Pentingnya Menjaga Hak Konstitusional Warga Negara di Indonesia. Diunduh dari:

https://www.uii.ac.id/pentingnya-menjaga-hak-konstitusional-warga-negara-d iindonesia/, tanggal 15 September 2019

Naskah Akademik RUU Perlindungan Data Pribadi. Diunduh dari: https://www.bphn.go.id/data/documents/na_perlindungan_data_pribadi.pdf, tanggal 16 September 2019 